\title{
Antikçă̆ Kaynaklarında ve Sonraki Seyahatnamelerde Kastamonu Kıyıları
}

\author{
The Kastamonu Coastline in Ancient Sources and in the Travelogues \\ of Later Periods
}

\begin{abstract}
Murat KARASALIHOĞLU*
Öz: Antikçağda Paphlagonia Bölgesi’nin sınırlarında yer alan Kastamonu, günümüzde Batı Karadeniz Bölgesi sınırları içinde kalır. Altı ilçesi bulunan Kastamonu şehrinin Karadeniz boyunca 170 km'lik bir sahili bulunmaktadır. Bu ilçelerin tümü antikçağ kayıtlarında belgelenen antik kentler üzerine kurulmuş ve bazıları antik isimlerinin kısmen değişmeleri ile günümüze gelmiştir. Kastamonu kıyılarındaki antik yerleşimlere dair yazılı kaynaklar Homeros ile başlayıp Bizans Dönemi sonlarına kadar devam etmektedir. Daha sonra kaleme alınan seyahatnameler ise bölgedeki yerleşimler hakkında detaylı bilgiler sunmuşlardır. Bu bağlamda sahil bandı üzerindeki yerleşimler, yakın çevresinde olan Herakleia Pontike (Karadeniz Ereğli), Amastris (Amasra) ve Sinope (Sinop) gibi doğal limanlara sahip olmamasından dolayı söz konusu bölgede yer alan yerleşimlerin çok fazla gelişemedikleri görülmektedir. Bu çalışma, kente ilişkin antik kaynakların ve 20. yüzyıl başına kadar buraya ziyarette bulunmuş seyyahların eserlerinden elde edilen coğrafi, ekonomik ve sosyo-kültürel bilgilerin değerlendirmesini amaçlamaktadır.
\end{abstract}

Anahtar sözcükler: Kastamonu, seyyah, seyahatname, Kytoros, Abonuteikhos, Aigialos

\begin{abstract}
Kastamonu, within the borders of the Paphlagonia Region in antiquity, is today in the Western Black Sea Region. The length of the Black Sea coastline of the province is 170 kilometers. Six of the towns in the province are located on the western coast of Black Sea. These towns were established at the sites of the ancient cities mentioned in the ancient records and the names of some of these towns have changed only a little since antiquity. References to these settlements in written sources began with Homer and continued into the end of the East Roman Period. The sources from later periods provided more detailed information concerning these places. According to these sources, the settlements along this coastline did not play an important role in history due to the lack of natural harbours, like those in nearby Herakleia Pontica (Karadeniz Ereğli), Amastris (Amasra) and Sinope (Sinop). In this study, the way these settlements are mentioned in the ancient sources and in travelogues written from the beginning of the Medieval period into the $20^{\text {th }}$ century are scrutinized, together with information concerning the archaeology, mythology, the social structure, economy and geography of this region.
\end{abstract}

Keywords: Kastamonu, traveller, travelogue, Cytorus, Abonuteichos, Aigialos

Günümüzde Karadeniz kıyılarında yer alan Kastamonu İli, yak. 170 km uzunluğunda bir kıyı şeridine sahiptir. Söz konusu sahil şeridindeki -bazıları ilçe merkezi olmak üzere- modern yerleşimlerin birçoğu antikçağdan itibaren sürekli iskân edilerek günümüze kadar ulaşmış ve birçok seyyah ile araştırmacının notlarında yer almıştır. Batıda Bartın, doğuda ise Sinop ile komşu olan Kastamonu'ya ait kıyı şeridi, batıda Cide ilçesi Kapısuyu mevki (Kapısuyu Çayı), doğuda ise Çatalzeytin ilçesindeki Akçay Deresi ile sınırlanmıştır (Fig. 1). Denize dik dağların

\footnotetext{
*Arkeolog, Kastamonu Valiliği Kent Tarihi Müzesi, Kastamonu, paphlagonia@gmail.com
} 
kıyı çizgisinin hemen ardında yükselmesi nedeniyle iç kesimlerle bağlantısı zorlu bir coğrafyaya sahiptir. Antikçağda ise Halys (Kızılırmak) ile Parthenos (Bartın)/Billaios (Fiyos Çayı) ırmakları arasında kalan, kuzeyinde Pontos Eukseinos (Karadeniz), güneyinde Galatia, güneydoğusunda Kappadokia, güneybatısında Phrygia ve batısında Bithynia bölgeleri ile sınırlandırılan Paphlagonia Bölgesi'nde yer almaktadır (Strab. XII. 3. 9).

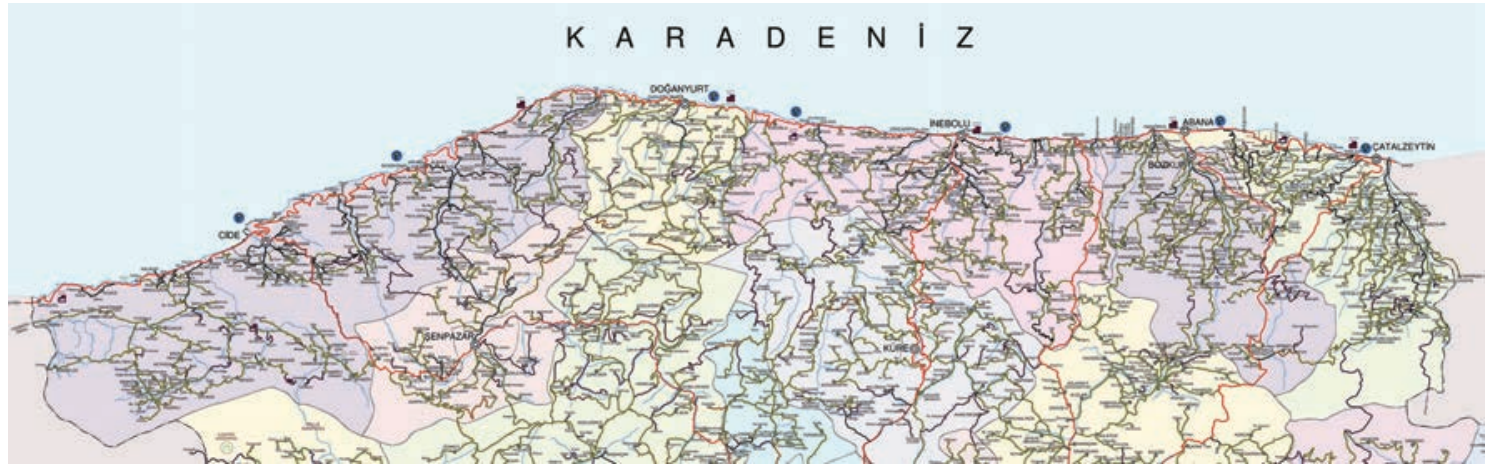

Fig. 1. Kastamonu Karadeniz kıyıları ilçe ve köyleri; 1/170.000 ölçekli Kastamonu Köy Yolları Haritası

Paphlagonia Bölgesi'nin iç bölgelerine ilişkin kaynaklar genel anlamda Prehistorik çağlara kadar geri gitse de (Kökten, 1951; Bostanc1, 1952, 137-140), kıyılara ilişkin en erken tarih belirsizdir. Ancak bölgeye ait ilk kaynak olan Homeros, Paphlagonia içerisindeki yerleşimleri sayarken Kytoros ve Aigialos'u Troia'ya destek veren kentler arasinda anmaktadır (Hom. Il. II, 850-855). Bölge M.Ö. VII. yüzyılda Kimmer istilasını yaşar (Ruge, 1949, 2516 vd.). Kroisos Dönemi’nde M.Ö. 561-546 y1llarında Lydia hâkimiyetine giren bölge (Hdt. I, 16), Kroisos'tan sonra Pers hâkimiyeti altında Phrygia satraplığına bağlanır (Hdt. I, 6-28-72). M.Ö. 333 yılına gelindiğinde ise Büyük İskender yönetimine boyun eğer (Ruge, 1949, 2516 vd.). M.Ö. 298 y1lında Mithradates I Ktistes, Olgassys Dağları'ndaki Kimiata da Mithradates Hanedanlığı'nı kurarak bölgeyi hâkimiyeti altına alır (Strabon, XII, 3. 41). Dönem içerisinde çeşitli yerel ve bölgesel krallıklar arasında el değiştiren Paphlagonia, M.Ö. 71-70 yıllarında Roma komutanı Lucullus tarafindan kıyı kentlerinin alınması, M.Ö. 64 yılları arasında ise komutan Pompeius Magnus tarafindan tüm bölgenin ele geçirilmesiyle Roma İmparatorluğu'nun sınırları içerisine girmiştir (Magie, 1950, 369).

M.S. X. yüzyıl ve sonrasında Venedik ve Ceneviz şehir devletlerinin ticari faaliyetleri bölgede dikkat çeker. Venedik Cumhuriyeti, 992 ve 1082 'de yaptığı anlaşmalarla ticari açıdan önemli ayrıcalıklar elde eder. Benzeri ticari antlaşmaların, Cenevizlilerle de yapıldığı görülmektedir. 1142,1155 'de ve 1261 'de yapılan anlaşmalarla Cenevizlilere de ayrıcalıklar tanınmıştır. Karadeniz ticaret rotası üzerindeki Ceneviz kolonileri; Finogonya (Kefken), Amastris (Amasra), Sinope (Sinop), Amisos (Samsun), Vatiza (Fatsa) ve Trabzon'dur (Ostrogorsky, 1986, 331-415; 452-486). Bu dönemde Karadeniz'de Ceneviz ve Venedik kolonilerinin genel olarak deri, kürk, buğday, köle, şarap ve baharat için önemli ticari faaliyetlerde bulundukları bilinmektedir (Di Cosmo, 2010, 83-108). 1071 sonrası Anadolu'ya gelen ilk Türk kuvvetleri Karadeniz'e ulaşamamışlardı. Bölge, 1204 yılında kurulan Trabzon Pontus Devleti'nin himayesi altındadır. Sultan I. İzzeddin Keykavus (1210-1219) tarafından M.S. 1214 yılında Sinop'un alınmasıyla bölgede Selçuklu hâkimiyeti başlamıştır (Turan, 1993, 303-307). Selçuklu Devleti'nin tarih sahnesinden silinmesine paralel olarak, Pervane, Çobanoğulları ve Candaroğulları beylikleri bölgenin hâkim güçleri olarak ortaya çıkarlar. 1460 yılından itibaren ise bölge Osmanlı hâkimiyeti altına girer (Yücel 1988).

Arkeolojik çalışmaların henüz yetersiz olduğu bölgede son dönemlerde yapılmış en kapsam- 
11 araştırma Cide Arkeoloji Projesidir (Düring, \& Glatz, 2010, 203-213; Düring, \& Glatz, 2011 188-201; Düring, \& Şerifoğlu \& Glatz, 2011, 237-250; Glatz, \& Düring and Şerifoğlu, 2011, 279-288; Şerifoğlu, \& Düring \& Glatz, 2012, 719-747; Düring, \& Glatz \& Şerifoğlu, 2012, 167 175). 2009-2011 yılları arasında yapılan kapsamlı yüzey araştırmaları Kastamonu kıyılarının hem Kuzey Karadeniz kıyıları hem de Anadolu kültürleriyle olan ilişkisi açısından önemli sonuçları göz önüne sermiştir. Öte yandan bulgular bölgenin Demir Çağı, Hellenistik, Roma ve Bizans dönemleri açısından da yazılı kaynakların verdiği bilgileri destekler görüştedir. Kıyılarda kurulmuş yerleşimler, M.Ö. VII-V. yüzyıllar arasında devam eden kolonizasyon, antikçağ sonrasındaki durum, kıyılardaki faaliyetler gibi unsurların görülmesi açısından yazılı kaynaklar yapılacak arkeolojik çalışmalara bir ön ayak oluşturmaktadır. Kastamonu'daki kıyı kentlerini de içine alan yakın zamanda yapılmış başka bir önemli araştırma ise Ch. Marek (1993, 82-88, 155157, Kat. 1-5, 157, Kat, 6, 185, Kat. 111-115) tarafından gerçekleştirilen epigrafi çalışmalarıdır.

Antik kaynaklar ve sonrasındaki seyahatnameler göz önüne alındığında Kastamonu kıyılarının siyasi ve sosyo-kültürel yapısından ziyade coğrafi özelliklerine vurgu yapıldığı görülmektedir. Buna göre söz konusu bölgede güvenli limanlara elverişli coğrafi ve iklimsel koşulların bulunmayışı nedeniyle, antik kaynaklarda bölgenin gelişemeyen kentlerine ilişkin sınırlı bilgiler yer almaktadır. Buna rağmen deniz yolu kullanılarak yapılan seyahatlerde verilen bilgiler Kastamonu kıyıları açısından önem kazanmaktadır. Zira hem Paphlagonia Bölgesi hem de günümüz Batı Karadeniz Bölgesi kara ulaşımı açısından yakın zamana kadar pek tercih edilmemiştir.

Bu çalışmada, Homeros'tan başlayarak XII. yüzyıla kadarki kaynaklardan faydalanılmıştır. Öte yandan Venedik ve Cenevizliler'in Karadeniz'deki faaliyetlerine dair bilgilere kaynak eksikliği nedeniyle ulaşılamazken, daha sonra 15-20. yüzyıllar arasında başta Fransız ve İngiliz seyyahlar olmak üzere İtalyan ve Türk seyyahların çalışmaları değerlendirilmiştir. Ele aldığımız antik kaynaklar içerisinde günümüz Kastamonu kıyıları sınırlarındaki antik yerleşimler batıdan doğuya doğru şu şekilde sıralanmaktadır: Kytoros (Gideros Koyu, Sütlüce), Aigialos (Cide Merkez ve sahili, eski Karaağaç), Klimaks (Kazallı), Thymena-Timoloium (Denizkonak ve Uğurlu Köyleri arası), Karambis (Kerempe Burnu-İlyasbey Köyü), Kallistratia (Doğanyurt), Zephyrion (Kayran), Garium Lokum (Özlüce), Abonuteikhos/Ionopolis (İnebolu), Aiginetes (Hacıveli) ve Kinolis (Ginolu).

\section{Kytoros}

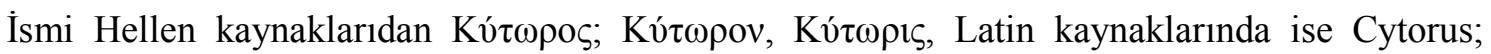
Cytorum; Cytorioca ve Cytheros şeklinde kullanılan Kytoros (Ruge, 1924, 224; Zgusta, 1984, 654-1; Belke, 1996, 245-246) antik yerleşimi günümüzde Cide ilçe merkezinin batısındaki Gideros Koyu'na konumlandırılmaktadır (Hom. II, 850-855; Skylaks Perip. 90; Theophr. hist. plant. III. 15. 10; Apoll. Rhod. argon. II. 940-950; II. 1155; Catull. IV. 10-13; Verg. Georg. 2. 426-436; Strab. XII. 3. 10-12; Ovid. Met. IV. 305-312, V. 127-133; Val. Flac. V. 101-110; Plin. nat. VI. II. 2 (2); XVI. 28; Mela I. 104; II. 3; Arr. Periplus XIV; Ptol. geogr. V. I; V. IV; Marcian. Perpl. 570-571; Tabula Peutingeriana, IX. segmentum; Steph. Byz. Ethnika 399. 10-15; Suda. 639; Const. Proph. De Adm. Imp. I. 29; Eust. 275).

Homeros Ilyada adlı eserinde Kytoros'u Troia saflarındaki bir Paphlagonia kenti olarak siralar. Homeros'un yanı sira, Apollonius Rhodius, G. Valerius Flaccus, Arrianus, C. Ptolemaios, M. Heraclensis, Tabula Peutingeriane (Fig. 2), S. Byzantinos, Suda, C. Prophygenitus VII ve Thesalonikili Eustathius da kentin coğrafi konumu ve çevre yerleşimlerle olan mesafeleri konusunda bilgi veren yazar ve eserlerdir. Bölgede mitolojik bir kökene sahip yegâne antik kent olan Kytoros'un bu özelliğinden Strabon ve P. Mela, kentin isim kökenini bir başka antik yazar olan 
Apheros'a dayanarak Argonautlar Seferi'ndeki başkahramanlardan Phryksos'un oğlu Kytissorus'tan (Apoll. Rhod. argon. II. 1155; Val. Flac. V. 462) aldığını söylemektedir. Aynı zamanda Strabon kentin Sinope'nin bir dönemler ticaret kenti olduğunu, Mela ise bir Miletos kolonisi olduğunu bildirir. Skylaks bir Hellen kenti olduğunu yazarken Stephenos Byzantinos ise kenti "polis" olarak tanımlar. Bunların yanı sıra Theophrastos, Apollonius Rhodius, Strabon, P. Vergilius Maro, Thesalonikili Eustathius da yörenin şimşir ağaçlarından bahsetmektedir.

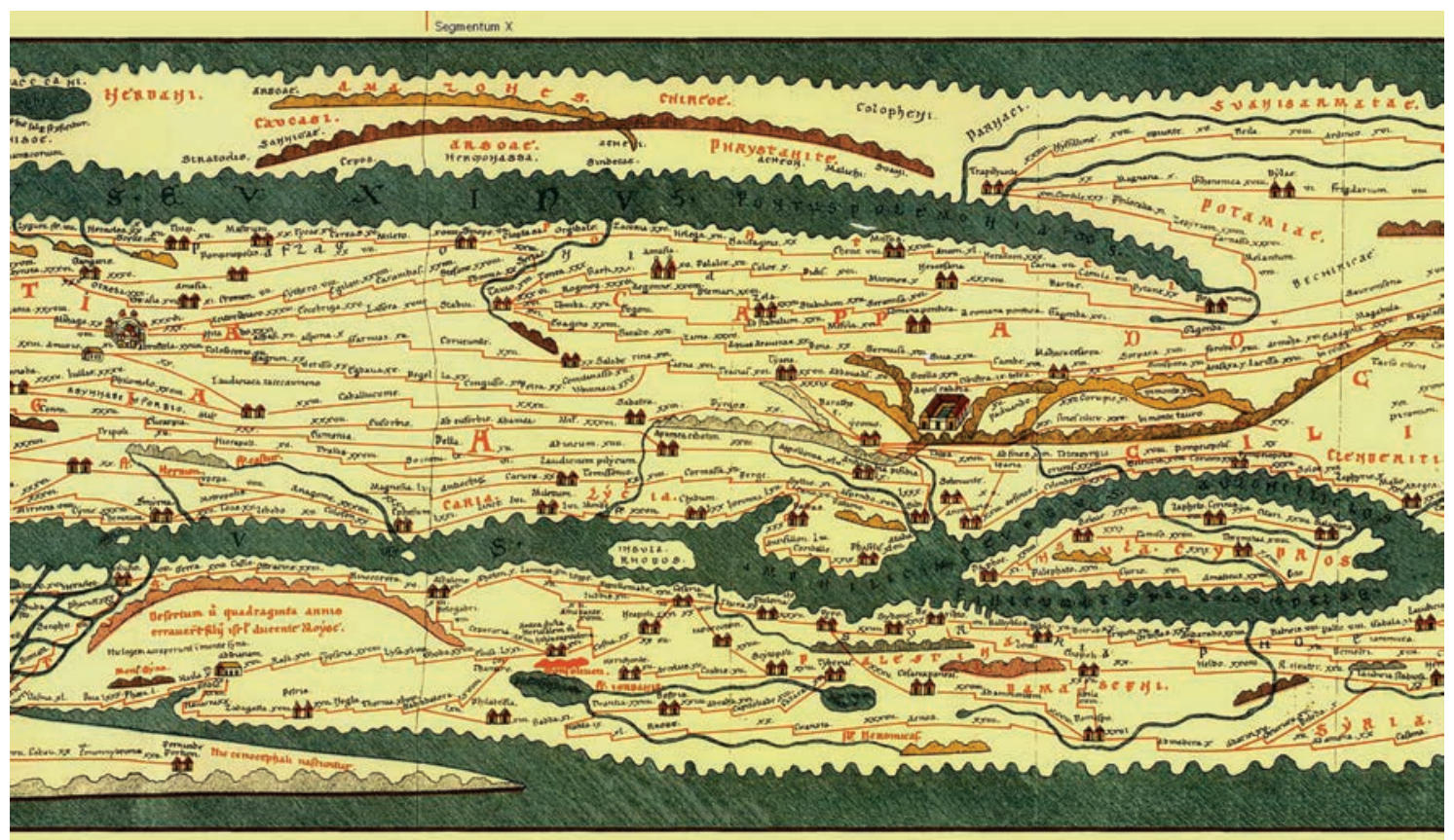

Fig. 2: Tabula Peutingeriana, http://www.hs-augsburg.de/ harsch/Chronologia/Lspost03/Tabula

Kytoros yerleşimi 15. yüzyıldan itibaren ortaçağ ve sonrasındaki seyahatnamelerde daha ayrıntılı olarak karşımıza çıkar (Tavernier, 1712, 337; Tournefort, 1741, 33; D'Anville, 1791, 298; Jaupert, 1821, 401-402; Leak, 1824, 307; Rottiers, 1829, 290-291; Cramer, 1832, 224; Fontanier, 1834, 60-61; Bore, 1840, 240-245; Hamilton, 1842, 159; Marigny, 1847, 33; Vivien, 1852, 454-455; Clavio, 1859, 58; Hommaire de Hell, 1860, 50-53, 235-238; Texier, 1862, 622; Hirschfeld, 1883, 275-281; Hommaire de Hell, 1954, 334-343; Bijiskyan, 1969, 25-27; Evliya Çelebi Sey. 74-75). Kastamonu kıyılarının Türk hâkimiyetine girmesinin ardından yöre ile ilgili ilk Batılı gezgin bilgisi 15. yüzyıl başlarında gelir. İspanya Kralının elçisi olarak 1403-1406 tarihleri arasında Timur'un devletinin başkenti Semerkand'a yolculuk yapan Ruy Gonzale De Clavio (? - 1412) Karadeniz'den geçerken güzergâhında Kytoros (Gideros) Koyu bulunmaktadır:

"Onlar o gün ve Perşembe günü kaldllar, sonra iyi bir Cuma günü onlar "İki kale olarak bilinen" bir limana akşam duasının yapılacă̆ saatte ulaştılar. Cumartesi günü gittiler ama yoğun bir sis vardı. Daha sonra orada yeni bir esinti oldu ve denizden büyük dalgalar yükseldi ve onlar karadan yakın ya da uzak olup olmadıklarını bilemedir" (Clavio, 1859, 57).

De Clavio, burada bilinen ismiyle Kytoros'u kullanmamış ancak iki kale şeklindeki tanımlamasıyla, küçük bir koy ve koyun girişini iki yandan saran doğal giriş ile bunlar üzerine yapılmış kaleleri (Şerifoğlu et alii, 2012, 730) belirlemektedir. Bu ifadeler Cide'nin Gideros Koyu'nda 
demirlediklerini açıkça göstermektedir. De Clavio, 25 Mart Salı gecesi Parthenos Irmağı'na (Bartın) ulaşmış ertesi günü de Amastris'e (Amasra) doğru ilerlemiş, burada konaklayarak yöre hakkında bilgiler vermiştir. Karadeniz'i konu edinen antikçağ yazarlarının ve sonraki seyyahların notları göz önüne alındığında Amasra'dan sonra gemiler için demirlenebilecek ilk nokta Gideros Koyu'dur. Bu noktada Clavio Cide sınırlarındaki Gideros Koyu'na 28 Mart Cuma akşamı ulaşmış ve geceyi burada geçirmiştir.

17. yüzy1lın en önemli gezginlerinden olan Jean-Baptiste Tavernier (1605-1689) doğuya yaptığı yolcukları kaleme aldığı seyahatnamesinde Karadeniz kıyılarındaki önemli yerleşimleri ve bunların birbirine olan uzaklıklarını vermiştir. Bu yerler arasında Quitros'u (Gideros) da saymış, burada sert rüzgârların olduğunu ve girişinin zor olduğunu belirtmiştir. 17. yüzyılda kıyılar hakkında bilgiler veren bir diğer gezgin ise din adamı olan Aleppolu (Halepli) Paul'dür (Paul Zaim, 1627-1669). 1654-1666 yılları arasında yazdığı "Patrik Makarius'un Seyahat Notları" ad11 eserinde Amastris'ten 50 mil ilerledikten sonra "Cetro" olarak anılan bir yere vardıklarını burasının İstanbul, Mısır ve birçok ülkenin gemiler için direk, ahşap ve donanım almak için başvurdukları tanınmış bir yer olduğunu söyler (Aleppo, 1836, 425). Günümüzde de Amasra kentinden doğuya doğru 50 mil ilerlendiğinde ulaşılan yer Gideros (Kytoros)'tur. Aynı zamanda diğer tarihsel kaynakların verilerine de bakıldığında bölgedeki gemi yapımı ve ağaç hammadde sektörünün gelişkinliği de seyyahın Cetro olarak verdiği yerleşimin Cide kıyıları, büyük ihtimalle de Gideros olduğunu gösterir.

Gideros mevkinden Evliya Çelebi (1611-1682), Joseph Pitton de Tournefort (1656-1708), d'Anville (1697-1782), William Martin Leake (1777-1860), P. Amedee Jaupert (1779-1847), P. Minas Bijiskyan (?-1851), V. Fontanier (1796-1857), William John Hamilton (1805-1867), Edouard Chevalier Taitbout De Marigny, Xavier Hommaire de Hell (1812-1848), M. Vivien de Saint Martin (1802-1896), Charles Texier (1802-1871), Gustav Hirschfeld (1847-1895) genel anlamda kentin çağdaş isminin yanı sıra antik dönem ismi, coğrafi bilgiler ve ormanlık oluşu ile gemi yapımcılığının yaygınlığı ve küçük bir koy olarak küçük de bir limana sahip olması gibi bilgiler verirler. Bu dönemde antik Kytoros'un isminin, Kudros, Kidros, Kitross, Kidross, Kydros olarak eserlerde geçtiği görülür.

Seyyahlar arasinda Aleppolu Paul, Tournefort, Bijiskyan bölgedeki kereste hammadde ve gemicilik uğraşlarından bahseder. Ayrıca Tournefort'un Sita Irmağı ve Bijiskyan'ın da Sal Deresi olarak adlandırdığı yerin de günümüzde Gideros'un hemen doğusundaki Devrekâni Çayı olması muhtemeldir. Bunların dışında Bernard Eugène Antoine Rottiers (1771-1858), Gideros Koyunda bir gece konaklar. Rottiers, Kytoros limanında karaya çıktıktan sonra bir dervişin hasta kızını iyileştirmek için muska yazdığından ve kıyıdan biraz uzakta zarif bir şekilde oyulmuş antik bir mezar gördüğünden bahseder. Ayrıca, limandaki caminin inşasında kullanılan Korinthos düzenindeki sütun vb. devşirme malzemeler hakkında bilgiler verir, sözü edilen caminin Yunan Tapınağı üzerine yapılmış olabileceği anektotunu da notlarına ekler (Rottiers, 1829, 290-291). Günümüzde Gideros Koyu, Sütlüce Mahallesinde eski bir cami bulunmaktadır. Fakat bu caminin kitabesinden caminin inşasının Hicri 1313 miladi 1897 tarihine tekabül ettiği anlaşılmaktadır. Hem bu tarihe bakarak hem de Rottiers'in bahsettiği antik devşirme malzemelerin bulunmadığ 1 günümüz camisinin Rottiers'in gördüğü camiden sonra onun yerine yapıldığı söylenebilir. Fransız şarkiyatçı Eugene Bore'de (1809-1878), bir gece Gideros Koyuna demirledikten sonra koya yakın bir mevkide yörenin önde gelen şahıslarından Ahmet Hasan Çelebioğlu'nun evinde bir gece konaklamıştır. Bu sayede bölgenin coğrafi, sosyo-kültürel, tarihi ve ekonomik dokusuna ilişkin bilgiler aktarmıştır. Aynı zamanda Kastamonu kıyılarının 19. yüzyıldaki panoramasına bakmak açısından çok önemli noktaları bize notları aracılı̆̆ıyla ulaştırmıştır 
(Bore, 1840, 240-245).

\section{Aigialos}

Aigialos, Aízı $\alpha \lambda o ́ \varsigma$, Egilen (Hirschfeld, 1894, 106; Belke, 1996, 158) antik yerleşimi günümüzde Cide ilçe merkezi ve onun sahip olduğu uzun kumsal olarak bilinmektedir. Aigialos antik kenti kaynaklarda Kytoros kentinin doğusunda yer alan ve genelde coğrafi konumu ve çevre yerleşimlerle olan mesafesi ile belirtilmiştir (Hom. II, 850-855; Apoll. Rhod. argon. II. 940-950; Strab. XII. 3. 10-12; Arr. Periplus XIV; Lucian. Alex. 56-57; Marcian. Perpl. 570-571; Tabula Peutingeriana, IX. segmentum; Steph. Byz. Ethnika 40. 10-25; Const. Proph. De Adm. Imp. I. 29; Anna Komnena, Alexiad, VIII. 9). Diğer kaynakların aksine Apollonius Rhodius, Aigialos kentini Kytoros ve Karambis kentlerinin arasına değil, Karambis’ten sonra yerleştirerek yanlış bir konum vermiştir. Yazarlardan, Apollonius Rhodius ve Strabon kenti tanımlarken uzun bir sahil olduğunu da eklemiş̧tir. Günümüzde Cide ilçe merkezinin sahili $10 \mathrm{~km}$ uzunluğuna sahiptir.

Ortaçağ kaynaklarına baktığımızda antik Aigialos kentinin isminin değiştiği görülmektedir (Kâtip Çelebi Cih. 288; Tournefort, 1741, 33; Jaupert, 1821, 401-402; Bijiskyan, 1969, 25-27; Marigny, 1847, 33; Hommaire de Hell, 1954, 334-343; 1860, 50-53, 235-238; Cuinet, 1894, 426, 452, 490-492). Tournefort seyahatinde isim vermese de Kerempe Burnuna gelmeden önce konakladığı uzun bir sahilden bahseder. Bu sahilin, kumsalı ile ünlü antik Aigialos olması muhtemeldir. Seyyahlar, bölgeyi Kara Agatch (Kara Ağaç), Tschida (Cide), Djidde (Cide) ve aynı mevkide kalan Kara Agatch Burnu (Kara Ağaç Burnu-günümüzde Köpek Burnu) olarak adlandırmışlardır. Taitbout De Marigny, burada yerleşimin az olmasına karşın oldukça büyük gemiler yapılıyor olmasının şaşırtıcı olduğunu belirtir. V. Cuinet (1833-1896) ise Düyun-u Umumiye adına Osmanlı Devleti'nin resmi görevlisi olarak Cide Kazası üzerine tarım, hayvancılık, madencilik ve sanayi gibi konularda incelemiş, yöre hakkında ekonomik analizler yapmıştır. Bunun yanı sıra yörenin tarihi, sosyo-kültürel durumu ve demografik yapısıyla ilgili kapsamlı bir rapor hazırlamıştır (Cuinet, 1894, 426, 452, 490-492).

\section{Klimaks}

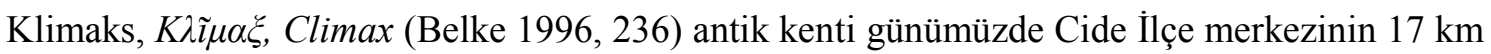
doğusundaki Kuşçu Köyü'ne ait Kazallı Mahallesi'nde yer alır. Antik kaynaklar yörenin konumunu belirtmekle birlikte burada bir kale olduğunu da göstermektedir (Ptol. geogr. V. I; V. IV; Marcian. Perpl. 570-571).

\section{Thymena}

Cide'nin 30 km doğusundaki Uğurlu (Timle) Köyü'ne lokalize edilmektedir. Antik kaynaklar arasında bu yerleşim ya da yerleşimleri Arrianus, Thymena ( $\theta \dot{v} \mu \eta v \alpha)$ olarak, Macrianus ise

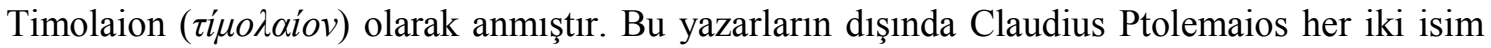
yerine Teuthrania yerleşimini saymıştır. Bu noktada Thymena-Timolaion ve Teuthrania isimlendirmesinde bir karışıklık var gibi görünmektedir Bu duruma bakarak aslında bu isimlerin aynı yer olduğu ya da birbirine çok yakın iki ayrı yerleşim olduğu düşünülebilir. Bu noktada belki de yerleşim ya da yerleşimler Uğurlu ve hemen batısındaki Denizkonak Köyleri arasına yerleştirilebilir. Thymena antik yerleşiminden (Arr. Periplus XIV; Ptol. geogr. V. I; V. IV; Marcian. Perpl. 570-571) konum ve bir kale olarak bahsedilmiştir.

Antik kent ortaçağ ve sonrasında hemen hemen isim değiştirmeden bazı seyyahların notlarinda yer alır. (Leak, 1824, 307; Jaupert, 1821, 401-402; Bijiskyan, 1969, 25-27; Hommaire de Hell, 1954, 334-343). Kent için Temeneh, Thimena gibi antik isminden pek de farklı olmayan şekli kullanılmıştır. 


\section{Karambis}

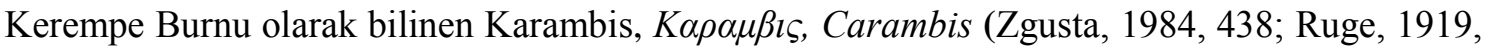
1937; Bekle, 1996, 226-227) günümüzde Cide İlçesi İlyasbey Köyü sınırlarında yer alır. Bu yerleşimden birçok antikçağ kaynağı bahsetmiştir (Skylaks Perip. 90; Apoll. Rhod. argon. II. 360-365; Strab. XII. 3. 10-12; Val. Flac. IV. 599; V.101-110; VIII.214; Plin. nat. II. I. 112; IV. 26; VI. II. 2 (2); XVI. 28; Mela I. 104; II. 3; Arr. Periplus XIV; Ptol. geogr. V. I; V. IV; Amm. Marc. 22.8.20; Marcian. Perpl. 570-571; Tabula Peutingeriana, IX. segmentum; Steph. Byz. Ethnika 40. 10-25; Suda. 565; Anna Komnena, Alexiad, VIII. 9). Kaynakların bir kısmı buray1 bir kent olarak nitelerken bir kısmı da sadece konumu ve bir burun olmasiyla birlikte kuzeyindeki kıyılarda yer alan Tauris Kriumepetopon'a olan konumuna göre değerlendirmiştir.

Antik kaynaklarda hem yerleşim hem de bir burun olarak yer alan Karambis, sonraki dönemlerde yazılan seyahatnamelerde sadece coğrafi anlamda bir burun olarak geçmektedir (D'Anville, 1791, 298; Jaupert, 1821, 401-402; Leak, 1824, 307; Vivien, 1852, 454-455; Hommaire de Hell, 1860, 50-53, 235-238; Texier, 1862, 622; Hommaire de Hell, 1954, 334343). Mevkinin isimlendirmesi ise genelde antik ismine bağlı kalarak küçük değişikliler göstermiş ve Kerempe, Kerembeh, Kerempeh, Kerembe, Keremhi, Kerçe, Pisello ve bir unvan olarak "Spartivento" (Rüzgâr ayırıcı) kullanılmıştır. Bölgeden bahseden seyyahlardan biri olan Bijiskyan (1969, 25-27) antik kaynaklara atıfta bulunarak, burada eskiden bir yerleşimin olduğunu ifade eder; Evliya Çelebi burnu oluşturan kayalıklar üzerinde dikkate şayan yazılar olduğunu belirtir (Evliya Çelebi Sey. 74-75). Tournefort (1741, 33), burnu Pisello olarak adlandırırken; De Marigyn $(1847,33)$ ise Spartivento adını hak ettiğini yazar.

\section{Kallistratia}

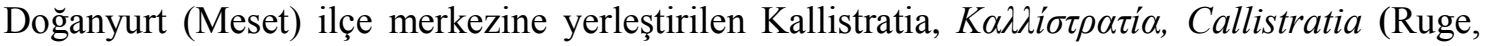
1919,1730; Belke, 1996, 223) antik yerleşiminden Claudius Ptolemaios ve Marcianus Heraclensis konum olarak bahsetmiştir (Ptol. geogr. V. I; V. IV; Marcian. Perpl. 570-571).

Kallistratia antik isimli yerleşim antikçağ sonrasında kimi seyahatnamelerde geçer (Cuinet, 1894, 426, 452, 490-492; Hommaire de Hell, 1954, 334-343; Katip Çelebi Cih.176). Yerleşim için bu seyahatnamelerde Hoşalay, Mezet, Gueuk-Alai (Gökalay) isimleri kullanılır.

\section{Zephyrion}

Zephyrion Zeqúpıov, Zephyrium (Danoff, 1972, 227-228; Belke, 1996, 284 ) antik yerleşiminden kaynaklar sadece konum olarak bilgi vermiş̧lerdir (Arr. Periplus XIV; Ptol. geogr. V. 1; 4). Yerleşim, Doğanyurt-İnebolu ilçe sınırında yer alan Kayran İskelesi'ne yerleştirilmektedir. Bu antik kentten sonraki dönemlerde ise Kairan olarak bahsedilmiştir (Hommaire de Hell, 1954, 334-343).

\section{Garium Locum}

Garium Locum, Ѓ́рıоv толоv (Ruge, 1912, 965; Belke, 1996, 199-200), günümüzde İnebolu ilçesi Özlüce (Zarbana) Köyünde yer alıp antikçağda sadece Marcianus Heraclensis'in eserinde yer alır (Marcian. Perpl. 570-571). Bu antik kentten sonraki dönemlerde ise Zefiyron ve Zarpana olarak bahsedilmiştir (Hommaire de Hell, 1954, 334-343; Bijiskyan, 1969, 25-27).

\section{Abonuteikhos/Ionopolis}

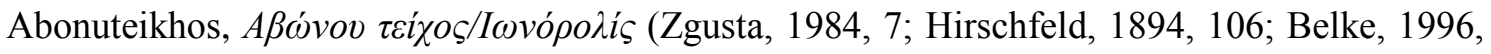
219-220) antik kenti bölgenin önemli bir yerleşimi olarak (Strab. XII. 3. 10-12; Arr. Periplus XIV; Ptol. geogr. V. I; V. IV; Lucian. Alex. 1-61; Marcian. Perpl. 570-571; Hierokles, 
Synecdemus 696. 2; Steph. Byz. Ethnika 9. 10-15; Cod. Iust. 29 C. 1; Const. Proph. De Adm. Imp. I. 29) antik kaynaklarda yer alır. M.S. II. yüzyılda Glykon Kültü'nün kurulması ve gelişmesi sonrasında ismi Ionopolis olarak değişir (Lucian. Alex. 57). Birçok kaynak kentten Abonuteikhos olarak bahsederken, Marcianus Heraclensis Abonuteikhos'un yanında bir açıklama ile sonradan Ionopolis olarak değiştiğini bildirir. Stephanus Byzantinos ise kenti bir "polis" olarak gösterir. Abonuteikhos/Ionopolis antik kenti (Fig. 3), Kastamonu kıyılarının önemli bir yerleşimi olarak ortaçağ ve sonrasındaki dönemlerde birçok seyahatnamede yer almıştır (Tavernier, 1712, 337; Tournefort, 1741, 33; D'Anville, 1791, 298; Jaupert, 1821, 401402; Leak, 1824, 307; Aleppo, 1836, 425-426; Marigny, 1847, 33; Vivien, 1852, 454-455; Clavio, 1859, 58; Hommaire de Hell, 1860, 50-53, 235-238; Texier, 1862, 622; Hirschfeld 1883, 275-281; Cuinet, 1894, 466-472; Nowack, 1931, 79-80; Hommaire de Hell, 1954, 334343; Bijiskyan, 1969, 25-27; Evliya Çelebi Sey. 74-75; Katip Çelebi Cih. 522). Yazarlar kent için, Ninopolis, Neapoli, Enapoli, Abono, Aineboli, Neopoli, gibi isimler kullanmışlardır.

Önemli bir antik geçmişe sahip ve daha sonraki yıllarda da önemi gittikçe artan Abonuteikhos/Ionopolis (İnebolu) yerleşimin hemen gerisinde yer alan Küre madenlerinin de 14-15. yüzyıl ortalarında yoğun olarak işletildiği ve Ceneviz ile Venedikliler tarafından ticarette kullanıldığ 1 bilinmektedir (Pitarakis, 1998, 141-185). $\mathrm{Bu}$ maden ticaret sahasının güvenliği için Ceneviz ve Venedikli tüccarların bölgeye ayrıca önem verdiği de düşünülebilir. Bu noktada İnebolu'nun da ortaçağ ticaretinde önem kazandığ 1 ve büyüme gösterdiği görülmektedir. Yoğun ticari artış ile Küre madenlerinin önemi ve ticareti, Kastamonu-İne-

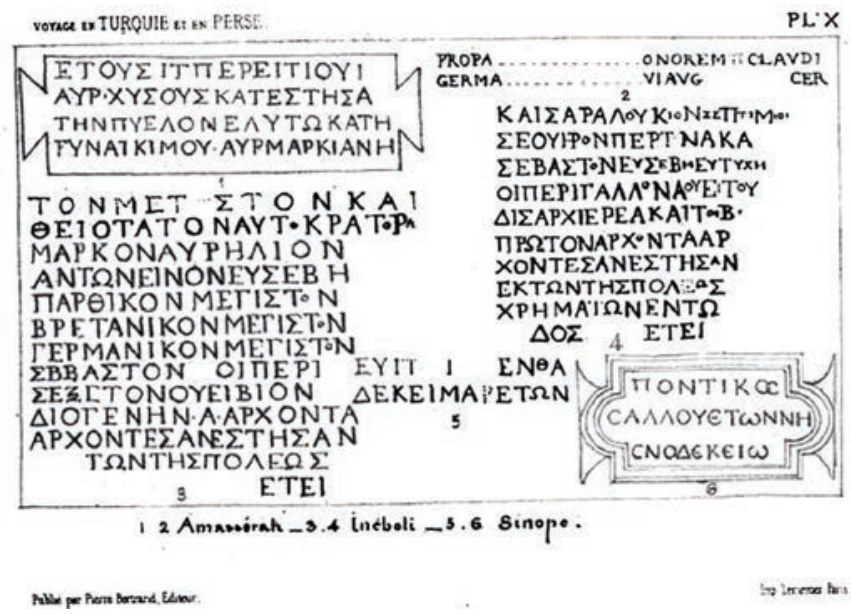

Fig. 3. Ionopolis'ten Antoninus Pius ve Septimus Severianus Dönemi yazıtları. Xavier Hommaire de Hell, 1860, 343-344, $\mathrm{X}, 3-4$. bolu bağlantısının yol ağları ile güçlendirilmesini ve iç bölgelerdeki malların kıyıya ulaştırılmasını sağlamıştır. Bunun yanında özellikle çam ve diğer kereste plakaları, kenevir ve kenevirden yapılan urgan, halat, sicim gibi malzemelerin ihracatı İnebolu'daki ticaret hayatını zenginleştirmiştir (Primaudaie, 1848, 262). Bu y1llardaki ticari faaliyetlerin yoğunluğuna ve çekişmelere bakılarak bölgedeki, özellikle kıyıda yer alan kalelerin tamirat geçirdiği ya da yeniden inşa edildiği (Şerifoğlu \& Düring \& Glatz, 2012, 731) düşünülebilir ve Kastamonu kıyı bandındaki kale yerleşmelerinin Amasra ile Sinop arasındaki tali ticaret üstlerinden biri olmaları da muhtemeldir.

Tournefort yerleşimi İstanbul ve Sinop arasındaki bir nirengi noktası olarak belirtip gemi yapımcılığının da öneminden bahsetmiş, aynı konuya Vivien de Martin, De Marigyn ve Jaupert de değinmiştir. Öte yandan Tournefort konakladığı yeri Abano olarak isimlendirmektedir. Günümüzde İnebolu'dan sonra Abana ilçesi ve sahili gelmektedir. Ancak antik ismiyle Aiginetes olan bu yerleşim demirlemek için çok uygun olmadığ 1 gibi, İnebolu'dan da daha küçük bir yerleşimdir. İnebolu'nun bilinen ilk isminin Abonuteikhos olması Tournefort'un sözü edilen kentte konaklamış olduğu fikrini akla getirmektedir (Tournefort, 1741, 36-37). Evliya Çelebi, İnebolu'nun tarihinden ve kalesinden bilgiler sunarken, 20. yüzyıl başındaki araştırmacı E. Nowack ise yerleşimin coğrafi ve tarımsal ürünleri hakkında bilgiler vermiştir. 


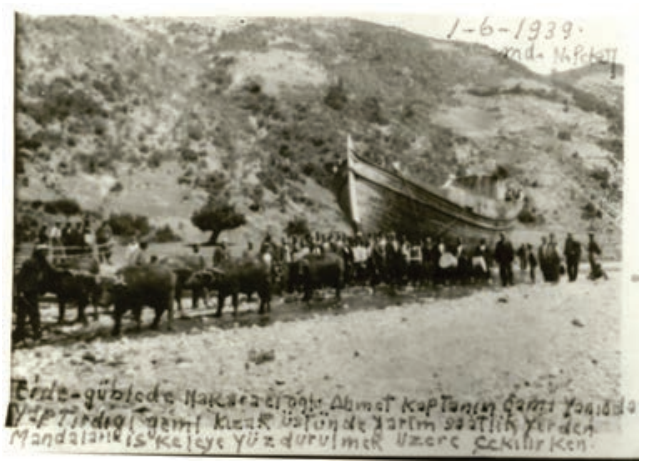

Fig. 4. Cide, Güble'de (Uğurlu Köyü) karada inşaa edilmiş bir teknenin dere içinden mandalarla kızak üstünde denize çekilmesi

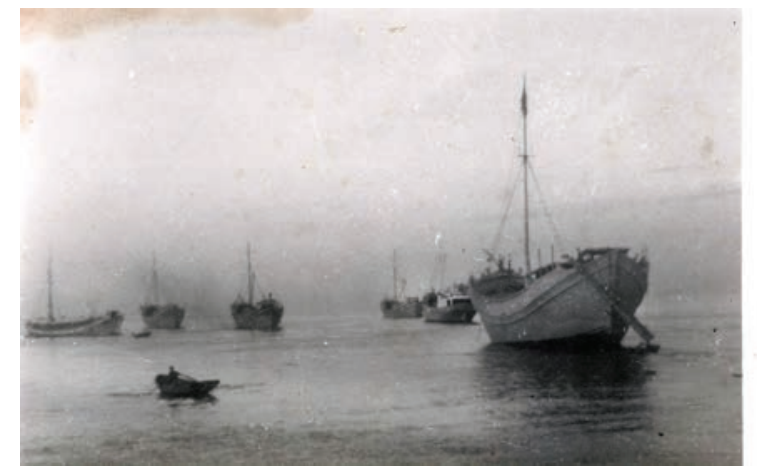

Fig. 5. Kastamonu Kıyılarında üretilen mavnalar, 1960'l1 y1llar.

\section{Aiginetes}

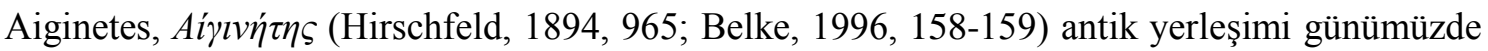
Abana ilçesinin $3 \mathrm{~km}$ doğusundaki Hacıveli bölgesine yerleştirilmektedir. Antik kentten az sayıda antik kaynak sadece konum olarak bahseder (Arr. Periplus XIV; Marcian. Perpl. 570-571; Steph. Byz. Ethnika 43. 10). Ancak Stephanus Byzantinos burası için "poliksenon" terimini kullanır.

Aiginetes yerleşimi, antikçağdan sonraki dönemlerde (D'Anville, 1791, 298; Hommaire de Hell, 1860, 50-53, 235-238; Cuinet, 1894, 466-472; Hommaire de Hell, 1954, 334-343; Bijiskyan, 1969, 25-27) kimi seyahatnamelerde yer almıştır. Yerleşim bu eserlerde, Ginue, Apana, Hadjvel-Oglu (Hacıvelioğlu) gibi isimlerle yer almıştır. Ancak burada Apana (günümüz Abana) ile antik Aiginetes arasında bir ayrım yapmak gerekmektedir. Çünkü ortaçağ ve sonrasındaki kaynaklarda Apana olarak zikredilen yerleşim bir iskele olarak görülmektedir. Bijiksyan buradan sonra Hacıveli yerleşimini saymakta ve özellikle Apana'nın doğu tarafında Ekinetes Çayı'nın aktığını söylemektedir. Bu isim mevki olarak Aiginetes ile örtüşmektedir. Bu bağlamda Apana İskelesi denen mevki, antik Aiginetes kentinde, muhtemelen sonraki y1llarda oluşmuş ya da büyümüş bir yerleşim yeri olduğu düşünülebilir.

\section{Kinolis}

Kinolis, Kivwגıs, Cinolis, Cimolis (Ruge, 1921, 435; Zgusta, 1984, 516; Belke, 1996, 232) antik kenti günümüzde Çatalzeytin İlçesi'nin 3 km batısındaki Ginolu Koyu'na yerleştirilmektedir. Bu antik yerleşimden bahseden kaynaklar şunlardır (Skylaks Perip. 90; Strab. XII. 3. 10-12; Plin. nat. VI. 2.2 (2); Mela I. 104; Arr. Periplus XIV; Ptol. geogr. V. I; V. IV; Marcian. Perpl. 570571). Genelde kentin ismiyle birlikte konum olarak değinilen kentten, Marcianus Heraclensis nehir kenarında yer alır diyerek daha belirleyici bir tespitte bulunur.

Yen-Yakınçağ seyahatnamelerinde de yer alan Kinolis kenti (D'Anville, 1791, 298; Jaupert, 1821, 401-402; Leak, 1824, 307; Vivien, 1852, 454-455; Clavio, 1859, 58; Hommaire de Hell, 1860, 50-53, 235-238; Bijiskyan, 1969, 25-27; Katip Çelebi Cih.), kaynaklarda antik isminden pek değişik olmayan Quinoli, Quinolou, Ginoli ve Kinoli gibi isimlerle yer almıştır.

Kaynaklarda sadece konumundan bahsedilen Kinolis için 15. yüzyıl kaynağı De Clavio'nun verdiği bilgiler özellikle Kastamonu kıyılarının Beylikler Dönemi için oldukça değerlidir.

"Gün ortasında kaleden geçtik, Ninopolis deniyordu, demirleyecek bir yer yoktu ve bu yüzden devam ettik. Akşam duası vakti sis geri döndü ve 
kara görünmüyordu. Gece çökmüş̧ӥ ve nerede olduğunu bilmiyorlardl. Bazılar limanı geçtiklerini söyledi. Onlar bir ara bir köpeğin havlamasını duydular ve bağırdılar. Kaledekiler onları duydu ve ışık gösterdiler. Gemi kıyıya yanaştı. Dışarısı kayalıktı ve denizi yarıyordu. Ve girişi bilmediklerinden tehlike içindeydiler. Denizcilerden biri kıyıdan yüzdü ve girişi aydınlatan bir ışı kaldı ve gemi güvenlice girdi. Paskalya günü limandaydık. Bu kayalığın üstünde güçlü bir kaleydi ve Quinoli diye anıllyordu. Burası ve birçok toprağın efendisi İsfandiyar (Yaşar Yücel, 1988, s. 83-99; Candaroğlu İsfandiyar Bey 1392-1439 yılları arasında beyliğin başıında bulunmuştu. Ayrıca Candaroğulları Beyliği Dönemi'nde Karadeniz klyısinda Venedik ve Cenevizlilerle ticari ilişkiler içinde oldu$\breve{g} u$ saptanabilen beyler arasında yer alır.) denen bir Mağribi'ydi. Timur Bey'e vergi veriyordu. Bunların parasi bu topraklarda kullaniliyordu. Efendi (Isfandiyar Bey) orada yoktu ama onun bir teğmeni gemide bir elçi olduğunu ögrenince yanında koyun, tavuklar, ekmek ve şaraptan oluşan hediyeleri ile geldi. Ouinoli Kalesi yanindaki orman çapraz yay için en iyi ă̆aç türünü barındırıyordu" (Clavio, 1859, 58).

Clavio'nun Kastamonu kıyılarını betimlediği dönemin Candaroğulları Beyliği’nin hâkimiyet yıllarına rastlaması oldukça dikkate değerdir. Özellikle Kinolis, koyundaki kalede Türk askerlerinin bulunduğu bilgisi, Bizans Dönemi sonrasında yöredeki kalelerin Türkler tarafından askeri amaçlar doğrultusunda kullanılıyor olduğunu göstermektedir. Öte taraftan, 1211/1212 (Yücel, 1988, 36) yılında Kastamonu'nun iç kesimleri Türklerin eline geçmesine rağmen kıyılarının ne zaman Türk Hâkimiyetine geçtiği belirsizdir. I. İzzeddin Keykavus'un 1214 yılında Sinop'u alması, ardından da Çobanoğulları Beyliği'nin hükümdarı Hüsameddin Çoban Bey'in 1223 tarihinde Suğdak seferine Sinop'ta hazırlanan donanma ile çıkması (Yücel, 1988, 38), Kastamonu kıyılarında Türk varlığının yayılmaya başlamış olabileceğini ifade eder.

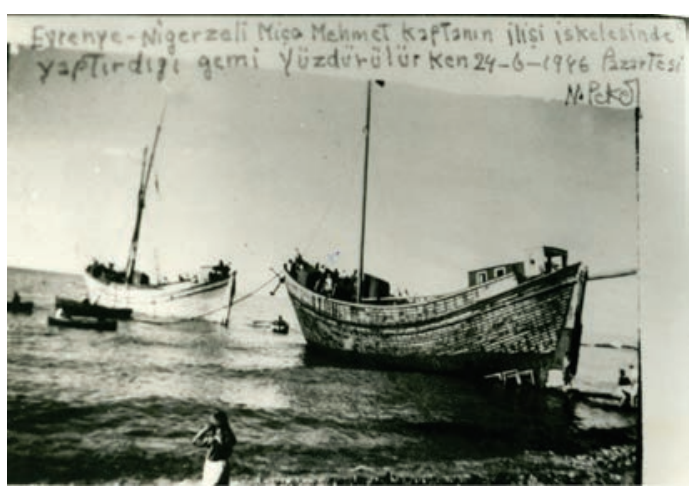

Fig. 6: Kastamonu kıyılarında üretilmiş bir mavnanın suya indirilmesi, yıl 1946.

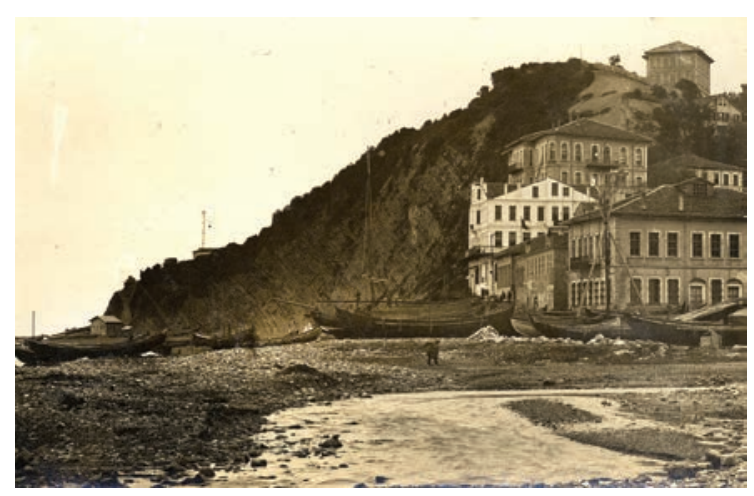

Fig. 7: Antik Abonuteikhos/Ionopolis günümüz İnebolu kıyısı, 1920'ler.

\section{Sonuç}

Antik kaynaklar ve sonrasındaki tarihsel kayıtların verdiği bilgiler çerçevesinde seyyahların notları üzerine yapılan incelemede Kastamonu kıyılarının yaklaşık 2500 yıldır yazılı kayıtlara geçtiği ve Karadeniz'in güney sahillerini kullanarak seyahat eden araştırmacıların bölge üzerine birbirini tamamlayan bilgiler verdiği görülmektedir.

Kastamonu kıyıları mitolojik kökene sahip tek yerleşim Kytoros kentidir. Kentin ayrıca Aigialos kentiyle birlikte Homeros'un Ilyada'sında anılması Karadeniz kolonizasyonunun erken 
dönemlerinde ortaya çıktığı bilgisini verir. Bunun dışında bölgedeki en önemli tarihsel olay ise Abonuteikhos kentinde M.S. II. yüzyılda ortaya çıkan ve geniş bir çevreye yayılan Glykon Kültü'dür.

Çağlar boyunca kaynaklar Kastamonu kıyılarının yoğun ormanlarla kaplı olduğundan bahsetmiştir. Ortaçağ kaynakları bölgenin, özellikle Konstantinopolis'in ihtiyaç duyduğu donanmaların önemli bir yapım yeri olduğunu belirtmesi gibi Tournefort'un henüz 1700'lerin başında bölgede imparatora (Padişah) ait birçok tersane, ambar ve liman bulunduğunu, tüm kıyı köylerde yaşayanların çivi, yelken, halat ve gemi inşatlarında çalıştığını söylemeleri bölge ekonomik faaliyetlerini görmek açısından önemlidir. Öte yandan Joupert'in İnebolu'daki tersanelerin yanı sıra bakırdan da bahsetmesi; İnebolu'nun hemen güneyindeki Küre Madenlerinden çıkarılan bakırın İnebolu limanı aracılığıyla başka yerlere sevk edildiğini göstermektedir (-7).

Hem antik kaynaklarda hem de ortaçağ seyahatnamelerde Karambis Burnu, Karadeniz'in kuzeyindeki Kriumepetopon Burnu ile Karadeniz'in en dar kesimini oluşturmasıyla sözü edilen denizi ikiye ayırdıklarının varsayımı burayı önemli kılmaktadır. Antikçağlardaki Karambis, Ortaçağ'da Fakas olarak isimlendirilmiştir, burası muhtemelen günümüzdeki İlyasbey Köyü'dür. Buradaki yerleşimden ortaçağda Anna Komnena değinmiş, 1608 yılındaki notlarında J. Bordier, buradaki kalıntılardan bahsetmiştir. 1972 yılındaki çalışmalarda yerel halkın Ceneviz Hamamı dediği ve çeşitli tuğla örgü ve yığma taş teknikleriyle inşa edilmiş kalıntıların ortaçağ yerleşimine ait olduğu belirtilmiştir (Bryer-Winfield, 1985, 67-68).

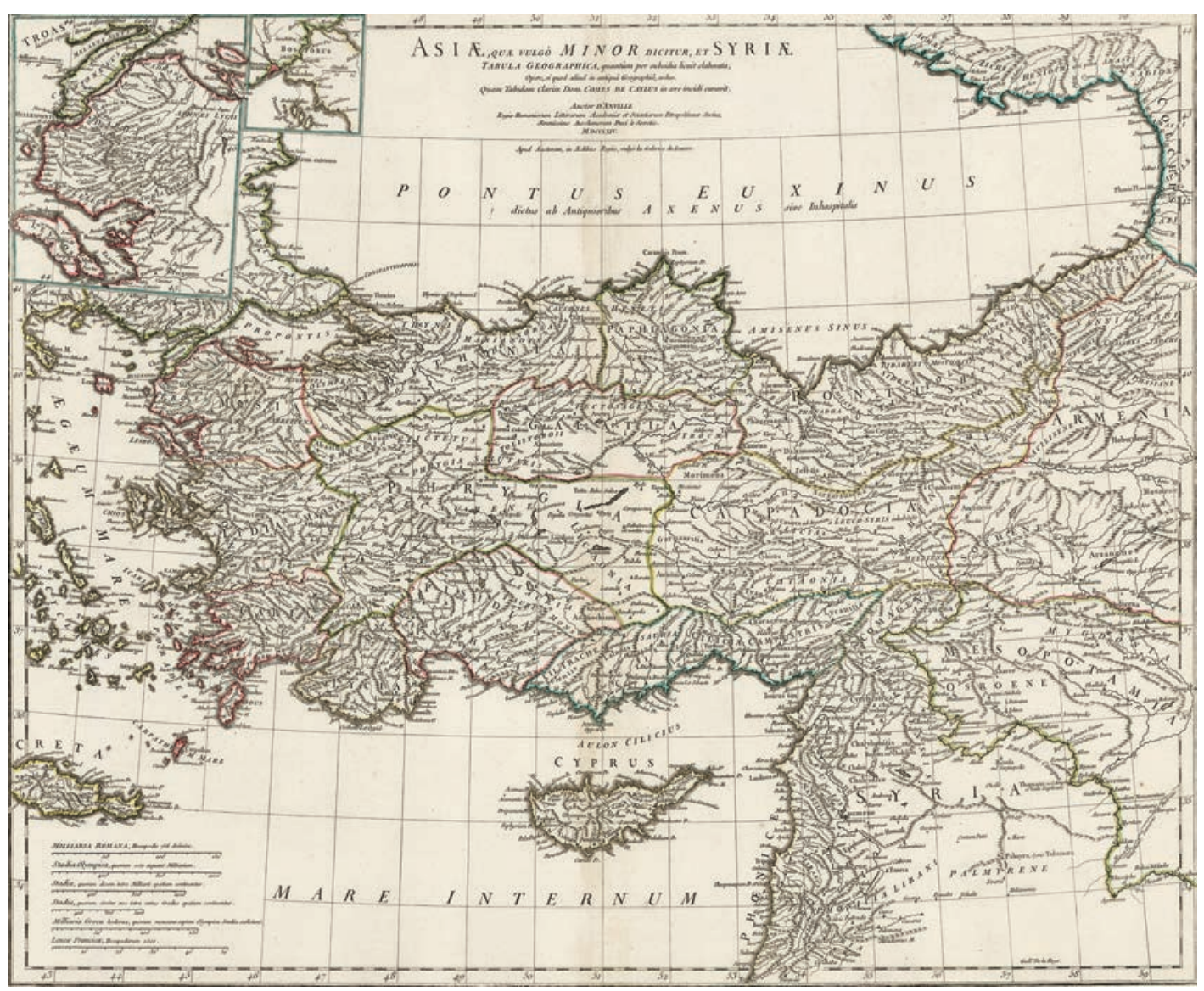

Fig. 8: Jean Baptiste Bourguignon D'Anville: Asiae, quae vulgo Minor Dicitur, et Syriae, Tabula Geographica; 1764, Paris; https://www.raremaps.com/gallery/detail/31636/Asiae_quae_vulgo_ Minor_Dicitur_et_Syriae_Tabula_Geographica/D'Anville.html 
Ortaçağ ve sonrasındaki seyyahlar genelde kıyıdaki yerleşimleri antik isimleriyle birlikte ele almışlardır. Bu noktada karşımıza çıkan en önemli bulgu yerleşim isimlerinin antikçağdan günümüze çok az değişimlerle ulaştığını göstermesidir.

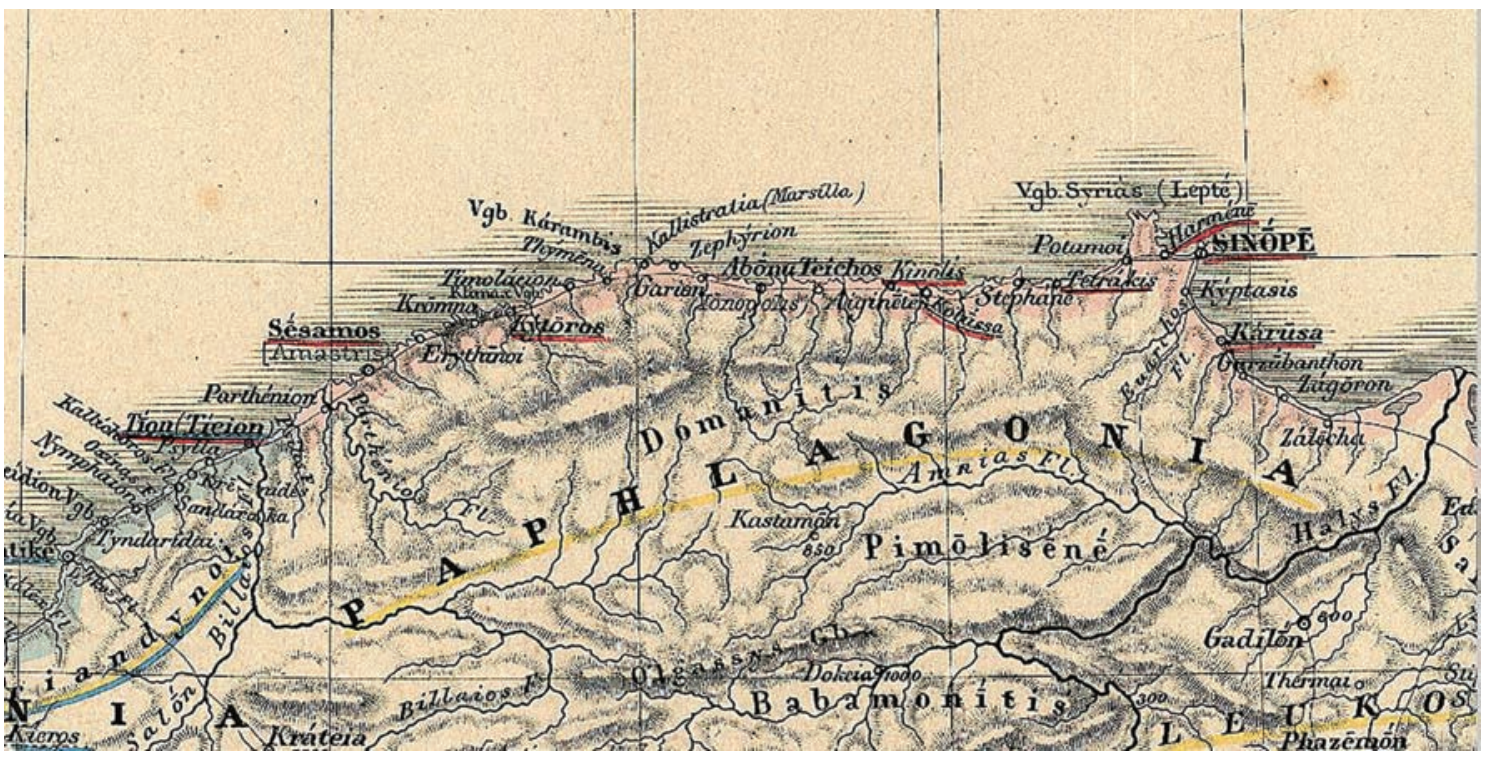

Fig. 9. Karadeniz Koloniler Haritası, H. Kiepert, Neuer Atlas von Hellas und den hellenischen Colonien in 15 Blätter, 1867, http://www.lib.uchicago.edu/lib/public/full_screen.html?http://www.lib. uchicago. edu/e/collections/maps/kiepert/G6811-S2-1872-K5-sheet10/

Antik yazarlarında vurguladığı Kytoros Dağı, Sagra Dağı olarak antikçağ sonrası kimi seyyahların notlarında yer almıştır. Burasının Cide'yi kuşatan ve yoğun şimşir ormanlarıyla kaplı Cide Dağları'nın olması yanında kimi seyyahların vurguladığ 1 etkileyici noktanın ise Gideros Dağı Kuşkayası Tepesi mevkisi olduğu düşünülebilir. Ayrıca bahsi geçen mevki D'Anville'in 1764 tarihli Asie quae vulgo Minor dicitur, et Syriae, Tabula Geographica (Fig. 8) ve H. Kiepert'in 1867 tarihli Atlas von Hellas und den hellenischen Colonien (Fig. 9) haritalarında Kytoros Dağı olarak gösterilmiştir.

Seyyahların zorunlu haller dışında karaya çıkmadıkları bilinmektedir. Bu duruma istisna olarak Bore ve Rottiers'in Gideros Koyuna demirlemeleri gösterilebilir. E. Bore, Kidros Limanı'na s1ğındığı zaman 1 mil uzaklıkta yer alan bir köy evinde ağırlanmıştır. Bu durum Kidros Koyu'nun iç kısmının eski dönemlerden beri yerleşim yeri olarak tercih edilmediğine işaret eder. Ayrıca seyyahın konakladığı köyün günümüz Abdülkadir Köyü olması muhtemeldir.

Seyyahların notlarında bölge antikitesine ilişkin antik yazarların bilgilerinin aktarılmasının dışında çok az bilgi bulunur. Bijişkyan, Gideros Koyu, Kinolis Koyu ve İnebolu'daki kale kalıntılarından bahsederken, E. Bore ve Rottiers ise Gideros Koyundaki kalıntılardan bilgiler vermişlerdir.

Karadeniz'i araştırma konusu edinmiş antikçağ yazarları ve sonraki dönem seyyahları arasında Kastamonu kıyılarına ilişkin bilgiler kısıtlı fakat oldukça değerlidir. Bölgede antikçağdan bu yana büyük bir yerleşimin olmaması, doğal limanların yer almaması, bölgenin coğrafi yapısının sarp ve zor olması gibi nedenler bilgi noksanlığının ana nedeni olmuştur. Ancak bölge ekonomik kaynakları, kıyı insanlarının ekonomik uğraşları, bölgenin etkileyici doğası, şimşir ve diğer birçok ağaç türü ile bir kereste deposu olması, özellikle önemli bir gemi üretim merkezi olmasına dair tüm bu bilgiler yaklaşık 2500 yıllık bir süreç içerisinde bu yazılı kaynaklarca bizlere sunulmuştur. 


\section{KAYNAKÇA}

\section{Antik Kaynaklar}

Amm. Marc. Ammianus Marcellinus, Rerum Gestarum Libri. Trans. J. C. Rolfe, Loeb Classical Library Cambridge London 1935-1939.

Apoll. Rhod. argon. Apollonius Rhodius, Argonautica. Trans. R. C. Seaton, London/New York 1919.

Arr. Periplus Arriannus, Periplus Ponti Euxini. Çev. M. Arslan, İstanbul, 2005.

Catull. Gaius Valerius Catullus, Carmina. Ed. C. Stuttaford, G. Bell and Sons 1912.

Cod. Just. Justinian I. The Code of Justinian and its Value. F. H. Blume, 1938; https://uwacadweb. uwyo.edu/blume\&justinian/code-and-value.asp

Const. Proph. De Adm. Imp. Constantinus Porphyrogenitus, De Thematibus et de Admintranto Imperio. I. Bekkerus, Bonn, 1840.

Eust. Eustathius of Thessaloniki, Eustathii Commentarios in Homeri Iliadem et Odysseam: Studio Mathaei Devarii. Lipsia,1828.

Hdt. Herodotos, Historia, Çev. M. Ökmen, İstanbul, 1991.

Hieroclis. Hieroclis, Synecdemus et Notitiae graecae episcopatuum: accedunt Nili Doxapatrii Notitia patriarchatuum et locorum nomina immutata. Trans. G. Parthey, Berlin, 1866.

Hom. II. Homeros, Ilyada. Çev. A. Erhat - A. Kadir, İstanbul, 2003.

Lucian. Alex. Lucianos, Alexandros Pseudomantis. Trans. A. M. Harmon, Loeb Classical Library 1925.

Marcian. Perpl. Marcian (Marciani Heracleensis). Menippi periplus maris interni (epitome Marciani). Geographi Graeci Minores. I. Ed. K. Müller, Paris 1855.

Mela. Pomponius Mela, De Chorographia. Trans. G. Parthy, Berolini 1867.

Ovid. Met. Puplius Ovidivus Naso, Metamorphoses. Ed. B. More, Cornhill Publishing Co. 1922.

Plin. nat. Gaius Plinius Secundus, Naturalis Historia. Trans. J. Bostock-H. T. Riley, London 1855.

Ptol. geogr. Cladius Ptolemaeus, Geographika Hyphegegis. Trans. and Ed. E. L. Stevanson, New York, 1932.

Skylaks Perip. Pseudo Skylaks, Periplous. Trans. G. Shipley, 2002

Steph. Byz. Ethnika Stephanus Byzantinus, Stephani Byzantii, Ethnicorum quae supersunt. Augustus Meineke, Berolini, 1849.

Strab. Strabon, Geographika. Çev. A. Pekman, İstanbul 2003.

Suda. Suda, Suidae Lexicon ex recognitione. I. Bekkeri, Berolini, 1854.

Tabula Peutingeriana. Annalina Levi ve Mario Levi, Itineraria picta: Contributo allo stüdyo della Tabula Peutingeriana. (Roma: Bretschneider) 1967.

Theophr. hist. plant. Theophrastus, Historia Plantarum. Trans. A. Hort, Loeb Classical Library, Harvard University Press, London 1999.

Val. Flac. Gaius Valerius Flaccus, Argonauticon. Trans. J. H. Mozley, Loeb Classical Library, No 286, Harvard Ubiversity Pres. 1934.

Verg. Georg. Vergilius Maro, Georgica. Ed. J. B. Greenough, Boston: Ginn \& Co., 1900.

\section{Modern Literatür}

Aleppo, P. (1836). The Travels of Macarius, Patriarch of Antioch: Part the Ninth: Conclusion of the Travels: Black Sea.-Anatolia- Syria. (Trans.: F. C. Belfour), London.

Alexiad. Anna Comnena (Komnene), The Alexiad. Ed. and Trans. E. A. Dawes. London: Routledge, Kegan, Paul, 1928.

Anonim. (1970). Türkiye Mülki İdare Bölümleri ve Bunlar Bağlı Köyler Belediyeler. Ankara: T. C. İçişleri Bakanlığ 1 .

Belke, K. (1996). Paphlagonien und Honorias (Tabula Imperii Byzantini, 9). Wien.

Bore, E. (1840). Correpondance et Memories D'un Voyageur en Orient. Tome I, Paris.

Bostanc1, E. (1952). "Gökırmak Vadisinde Prehistuvar Araştırmalar, Yeni Paleolitik Buluntular”. AÜDTCF 
Dergisi, IX (3), 137-142.

Bryer, A., \& Winfield, D. (1985). The Byzantine Monuments and Topography of the Pontos, II vols., Washington: Dumbarton Oaks Studies Twenty.

Clavijo, R. G. (1859). Narrative of the Embassy of Ruy Gonzales de Clavijo to the Court of Timur at Samarkand AD 1403-1406. (Trans.: C. R. Markhom), London.

Cramer, J. A. (1832). Geographical and Historical Description of Asia Minor with a Map. vol I, Oxford.

Cuinet, V. (1894). La Turquie D’Asia Geographie Administrative, Tome Quatime. Paris.

D’Anville, J. B. B. (1791). Compendium of Ancient Geography by MonsiurD'Anville. (Trans.: L. J. Horsley), London.

Danoff, M. Chr. (1972). “Zepyrium”. RE X, 227-228, Stuttgart.

Di Cosmo N. (2010). "Black Sea Emporia and the Mongol Empire: A Reassessment of the Pax Mongolica”. Journal of the Economic and Social History of the Orient, 53 (1-2), 83-108.

Düring, B, \& Glatz, C. (2010). "The Cide Archaeological Project 2009: First Results". Anatolia Antiqua, XVIII, 203-213.

Düring, B. \& Glatz, C. (2011). "2009 Cide Arkeoloji Projesi: İlk Sonuçlar”. AST 28/1, 188-201.

Düring, B. S., \& Glatz, C., \& Şerifoğlu, T. E. (2012). “The Cide Archaeological Project”. Anatolia Antiqua, XX, 167-175.

Düring, B. S., \& Şerifoğlu, T. E., \& Glatz, C. (2012). “2010 Cide Arkeoloji Projesi: İkinci Sezon Sonuçlar”. AST 29/3, 237-250.

Evliya Çelebi Sey. (1970). Evliya Çelebi Seyahatnamesi. Cilt 3, (Çev.: Z. Danışman), İstanbul.

Fontanier, V. (1834). Voyagen en Orient Entrepris Par Odre Du Governement Français De 1830A. 1833. Paris.

Glatz, C., \& Düring, B. S., \& Şerifoğlu T. E. (2011). "The Cide Archaeological Project 2010: Second Preliminary report". Anatolia Antiqua, XIX, 279-288.

Hamilton, W. J. (1842). Research in Asia Minor, Pontus and Armenia with Some Account of Their Antiquities and Geology. Vol I. London.

Hirschfeld, G. (1883). "Notes of travel in Paphlagonia and Galatia”. JHS, IV, 275-281.

Hirschfeld, G. (1894). “Aigialos”. RE, I (1-2), 106. Stuttgart; “Aiginetes”. RE, I (1-2), 965. Stuttgart.

Hommaire, de Hell, X. (1854). Voyage en Turquie et en Perse execute Par Ordre du Gouvernemnt Français. Tome Premie, Paris.

Hommaire, de Hell, X.. (1860). Voyage en Turquie et en Perse execute Par Ordie du Governement Français, Tome Quatrime. Paris.

Jaupert, A. P. (1821). Voyage en Armenia et en Perse 1805-1806. Paris.

Katip Çelebi Cih. (2008). Cihannüma, İstanbul: Boyut Yayın Grubu.

Kökten, K. (1951). “Kuzeybatı Anadolu'nun Tarihöncesi Hakkında Yeni Gözlemler”. AÜDTCF Dergisi, $\mathrm{X} / 2,201-214$.

Leach, J. (1986). Pompey the Great. New York: Routledge.

Leake, W. M. (1824). Journal of a Tour in Asia Minor: with Comparative Remarks on the Ancient and Modern Geography of that Country. London.

Magie, D. (1950). Roman Rule in Asia Minor to the End of the Third Century After Christ. II vols. Princeton.

Marek, C. (1993). Stadt, Ära und Territorium in Pontus-Bithynia und Nord-Galatia. Tübingen.

Marigny, E. T. (1847). New Sailing Directions for the Dardanelles, Sea of Marmara, Bosphorus, Black Sea and the Sea of Azov, London.

Minas, P. B. (1969). Karadeniz Kıyıları Tarih ve Coğrafyası 1817-1819, (Çev. H. D. Andreasyan), Istanbul Üniversitesi Edebiyat Fakültesi. İstanbul.

Nowack, E. (1931). “Journeys in Northern Anatolia”. American Geographical Society, 21/1, 70-91.

Ostrogorsky, G. (1986). Bizans Devleti Tarihi. Çev.: F. Işıltan. Ankara: TTK Basımevi.

Primaudaie, F. E. (1848). Études sur le commerce au moyen âge. Histoire du commerce de la mer Noire 
et des colonies génoises de la Krimée. Paris.

Rottiers, B. E. A. (1829). Itinéraire de Tiflis à Constantinople. Brüksel.

Ruge, W. (1912). "Garium Lokum”. RE, VII (1), 1766. Stuttgart.

Ruge, W. (1919). "Karambis". RE, X, 1937. Stuttgart; "Kallistrata” RE, X, 1730. Stuttgart.

Ruge, W. (1921). "Kinolis". RE, XI, 435. Stuttgart.

Ruge, W. (1924). "Kytoros". RE, XII (1), 224. Stuttgart.

Ruge, W. (1936). "Timoloian”. RE, VI (A.1), 1278. Stuttgart.

Ruge, W. (1949). "Paphlagonia". RE, XVIII (4), 2516-2537. Stuttgart.

Şerifoğlu, T. E., \& Düring, B. S., \& Glatz, C. (2012). "Cide ve Şenpazar 2009-2010 Y1lı Arkeolojik Araştırmaları". Belleten, 227, 719-747.

Tavernier, J. B. (1712). Les six voyages de JEAN BAPT. TAVERNIER en Turquie, en Perse et aux Indes I. Utrecht.

Texier, C. (1862). Asie Mineure, Description Géographique,Historique et Archéologique des Provinces et des Villes de la Chersonnése d'Asie. Paris.

Tournefort, J. P. (1741). A Voyage into the Levant. Vol III, (Trans.: J. Ozell) London.

Turan, O. (1993). Selçuklular Zamanında Türkiye. Ankara: Boğaziçi Yayınları.

Vivien, S. M. (1852). Description Historique et Geographique de L'Asia Mineure. Tome II, Paris.

Yücel, Y. (1988). Çobanoğulları ve Candaroğulları Beyliği I, Ankara: TTK Basımevi.

Zgusta, L. (1984). Kleinasiatische Ortsnamen. Heidelberg. 